\title{
Characteristics of Screen Mesh Wick Heat Pipe with Nanofluid as Passive Cooling System
}

\author{
W.N. Septiadi ${ }^{1,2^{\star}}$, N. Putra ${ }^{1}$, M. Juarsa ${ }^{1}$, I.P.A Putra ${ }^{1}$ and R. Sahmura ${ }^{1}$ \\ ${ }^{1}$ Department of Mechanical Engineering, Indonesia University, Depok 16425, Indonesia \\ ${ }^{2}$ Department of Mechanical Engineering, Udayana University, Badung 80364, Bali, Indonesia
}

\section{ARTICLE INFO}

\section{Article history:}

Received 04 December 2012

Received in revised form 13 February 2013

Accepted 25 February 2013

Keywords:

Passive Cooling

Heat Pipe

Nanofluid

Screen Mesh

\begin{abstract}
A B S T R A C T
The heat pipe is one of the cooling media which is potential to be developed for the passive cooling system for nuclear reactors. To enhance the performance of the heat pipe, nanofluids have been used as the working fluid for the heat pipe. This paper studies the characteristics of nanofluids as the working fluid of heat pipe with screen mesh wick, which was the mixture of nano-sized particles $\left(\mathrm{Al}_{2} \mathrm{O}_{3}\right.$ and $\left.\mathrm{TiO}_{2}\right)$ with water as the base fluid. The nanoparticles have average diameter of $20 \mathrm{~nm}$, made with $1 \%$ to $5 \%$ volume fraction. The heat pipe thermal performance was tested using heater with different heat load. The experimental result shows the use of $5 \%$ $\mathrm{Al}_{2} \mathrm{O}_{3}$-water improve the thermal performance by reducing the temperature at evaporator side as much as $23.7 \%$ and the use of $\mathrm{TiO}_{2}$-water reduce the temperature at evaporator side as much as $20.2 \%$ compared to the use of water. The use of nanofluid also decreases the thermal resistance of heat pipe. As the use of nanofluid improves thermal performance of heat pipe, it has a potential for applications along with heat pipes at nuclear reactors.
\end{abstract}

\section{INTRODUCTION}

In Indonesia, referring to the Government Regulation No. 5/2006 (PP 5/2006) on National Energy Policy, nuclear as a new energy source has to contribute more than $5 \%$ of national energy demand, along with other new and renewable energy source such as wind, water and solar [1].

Because of the higher risk due to its radioactive materials, designers and manufacturers of nuclear power plants have elaborated and continually striven to improve the safety aspects of nuclear power plants (NPPs). One safety system concepts being developed today is the passive safety systems, which is defined by IAEA-TECDOC-626 as a system that uses entirely passive structures and components or system that use active components in very limited quantities to initiate subsequent passive process [2]. One of the functions of the passive safety system is to taking decay heat after shutdown. Simpler and more reliable design for lower cost of operation and maintenance is the goal of the passive safety system [3].

One of the passive cooling medium for nuclear reactors which is potential to develop is the heat pipe. The heat pipe is a heat conducting technology using certain sized pipe containing a

\footnotetext{
* Corresponding author.

E-mail address: nata@me.unud.ac.id (W.N. Septiadi)
}

special fluid, functioning as a cooler, conducting heat from the pipe's hotter end to the cooler end. This cooling system was first announced and patented by R. S. Gaugler of General Motors in 1942. It was first demonstrated by George Grover at Los Alamos National Laboratory in 1962 and was published in physics journals in 1964 [4].

The utilization of heat pipes at nuclear facilities has been studied by Jouhara et al. who studied the potential use of heat pipe in a nuclear seawater desalination [5]. There, heat pipes were used as heat exchanger to dissipate waste heat generated from a nuclear reactor, and use the heat for water desalting process. The application of heat pipes as the autonomous emergency cooling down system also has been considered. Sviridenko proposed a passive emergency cooling down system based on heat pipes to be applied at nuclear power plant. It is explained that the application of heat pipe could increase the reliability and safety index to the basic NPP equipment [6]. As the heat pipe is being projected to be the passive cooling medium which take the decay heat after shutdown, it needs improvement in terms of thermal performance.

Several factors affecting the performance of a heat pipe are the working fluid, the wick structure and the geometry of the heat pipe [7-21]. From the development of nanotechnology and heat transfer, numerous efforts have been done to obtain better 
heat transfer. Wei et al. have conducted research on the effects of nanofluid concentration on heat pipe thermal performance. They showed that the concentration of nanoparticles in the base fluid improves the performance of the heat pipe [22]. Do et al. conducted a study to the thermal resistance of screen mesh wick heat pipes using the $\mathrm{Al}_{2} \mathrm{O}_{3}$-water nanofluid which yield the results that the volume fraction of $3 \% \mathrm{Al}_{2} \mathrm{O}_{3}$ nanofluid with water-based fluids can improve the performance of heat pipes significantly: heat at the evaporator is reduced by up to $40 \%$, and smaller thermal resistance [23]. Paisarn and Naphon examined the thermal efficiency of heat pipes with titanium nanofluid. The results suggested that the heat transfer efficiency of the heat pipe increases with the addition of nanoparticles volume percentage on the base fluid; by adding $0.1 \%$ volume fraction of nanoparticles, the heat pipe efficiency increased by $10.6 \%$ [13]. Liu examined the application of water-based $\mathrm{CuO}$ nanofluid in heat pipe with a horizontal mesh, with the result that addition of $1 \% \mathrm{CuO}$ nanofluid increased the heat transferred by up to $42 \%$ and decreased thermal resistance by up to $60 \%$ [14]. Several experiments conducted showed that nanofluid can increase thermal conductivity and has better heat transfer ability compared to other conventional fluids.

In this study, a comparison of the effects of the application of $\mathrm{A}_{2} \mathrm{O}_{3}$ and $\mathrm{TiO}_{2}$ nanofluids to the thermal performace of screen mesh wick heat pipe has been carried out. Up to this point, this kind of study has not been presented in other publications. The study's purposes are towofold, namely: first, to determine the effect of the nanofluid concentration to the thermal performance; and second, to determine the coating effect of nanoparticles on the screen mesh wick. It is hoped that the parameters yielding the best thermal performance could be determined.

\section{EXPERIMENTAL METHOD}

This study utilized $\mathrm{Al}_{2} \mathrm{O}_{3}$ and $\mathrm{TiO}_{2}$ nanoparticles both with the size of $20 \mathrm{~nm}$. The production of these nanofluids uses a two-step method. The nanoparticles were dispersed in the base fluid with ultrasonic processor at 100\% intensity for 60 minutes. Nanoparticles were dispersed in an ultrasonic processor to achieve a stable homogeneous solution. Afterward, the nanofluids were cooled at a constant temperature of $25^{\circ} \mathrm{C}$. The nanofluids were made in five concentrations (volume fraction), i.e. $1 \%, 2 \%, 3 \%$,
$4 \%$ and $5 \%$ at $100 \mathrm{ml}$. The quantity of alumina nanoparticles is determined by the volume fraction formula [23]:

$$
\begin{aligned}
& \% \text { volume fraction }=\frac{\frac{W_{a}}{\rho_{a}}}{\frac{W_{a}}{\rho_{a}}+\frac{W_{\text {basefluid }}}{\rho_{\text {basefluid }}}} \\
& \frac{1-\omega}{\omega} \cdot \frac{\rho_{p}}{\rho_{o}}=\frac{1-\varphi}{\varphi} \\
& \rho_{n f}=\left(\frac{1-\omega}{\rho_{o}}+\frac{\omega}{\rho_{p}}\right)^{-1}
\end{aligned}
$$

The characteristics of these nanofluids were tested by sedimentation tests as shown in Figs. 1 and 2 , that in some period of time, the nanofluid will form a line of separation between the nanoparticles and the base fluid. From the sedimentation test, it was obtained that the $\mathrm{Al}_{2} \mathrm{O}_{3}$-water nanofluid began to sediment on day 64 and $\mathrm{TiO}_{2}$-water sedimentation began on day 53 . This is better than the $\mathrm{Al}_{2} \mathrm{O}_{3}$ nanofluid made by Do, which started to sediment on day 25 [23].

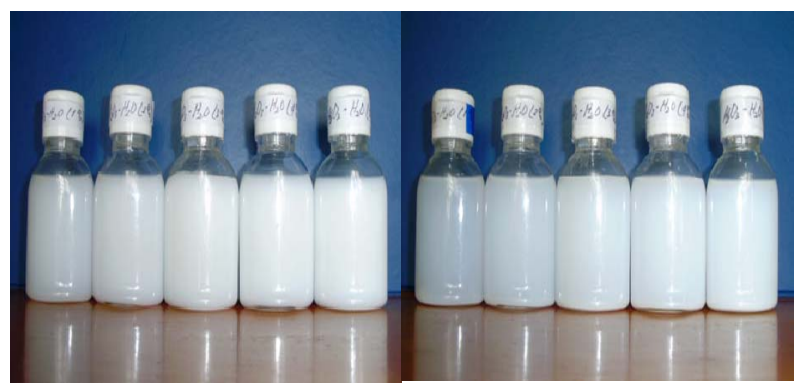

(a) Day 1

(b) Day 64

Fig. 1. $\mathrm{Al}_{2} \mathrm{O}_{3}$-water nanofluid.

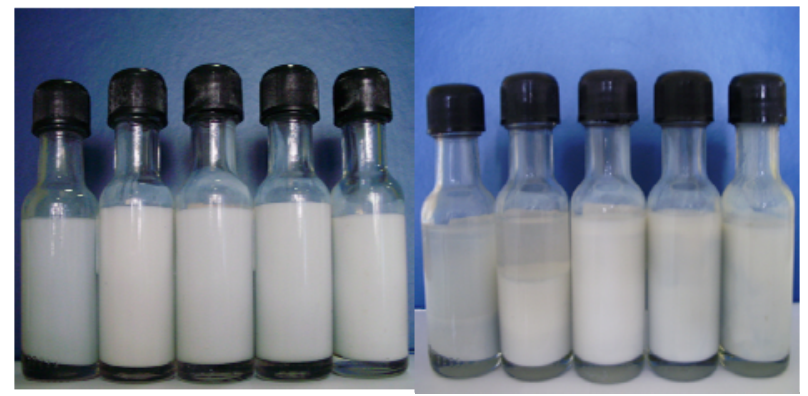

(a) Day 1

(b) Day 53

Fig. 2. $\mathrm{TiO}_{2}$-water nanofluid.

Heat pipes were built using copper pipe with diameters of $6 \mathrm{~mm}, 8 \mathrm{~mm}$ and $10 \mathrm{~mm}$, and with lengths of $200 \mathrm{~mm}, 300 \mathrm{~mm}$ and $400 \mathrm{~mm}$, with nepel valve at one end to insert the working fluid. They are $0.56 \mathrm{~mm}$ thick. The wick material is stainless steel 200 screen mesh with screen dimeter of $\pm 56.5 \mu \mathrm{m}$ and with 67.416 weavings per $\mathrm{mm}$, as 
shown in Fig. 3. Screen mesh wick was made by rolling 4 layer of screen and putting them on the inner wall of the heat pipe. The heat pipe design is shown in Fig. 4.

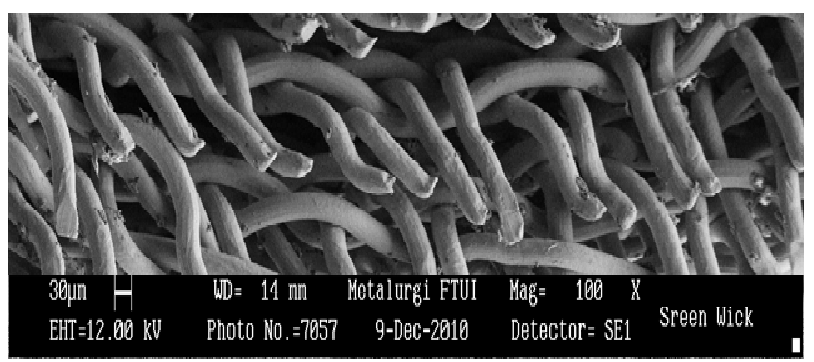

Fig. 3. Stainless steel screen mesh.

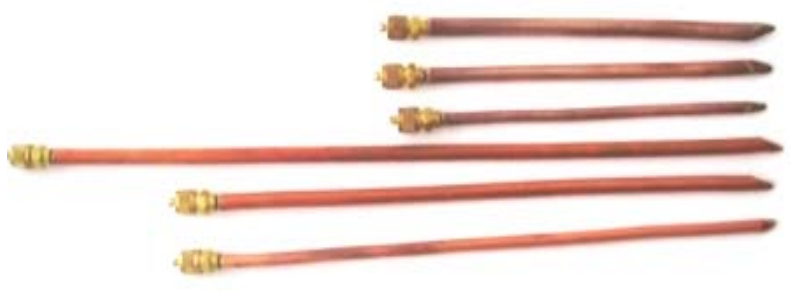

Fig. 4. Copper heat pipe with screen mesh wick.

Fig. 5 shows the schematic of the heat pipe testing which was conducted by measuring the temperature at several point in the heat pipe with thermoucople position as shown in Fig. 6. heat pipe was wrapped by cable heater (flexible heater). The adiabatic area was insulated using polyurethane box to avoid heat loss, while the condenser side was left open to let the heat transfer occurred by natural convection in the ambience temperature. After the setup complete, the power (Q) from the DC-power supply was given at 10 Watt, 15 Watt and 20 Watt. The temperature from several point of the heat pipe then was being measured by the thermocouples, and the data is processed using data acquisition cDAQ NI-9172 and NI 9211 module with LabView 8.5 data processing software.

\section{RESULTS AND DISCUSSION}

Figs. 7,8 and 9 show the temperature distribution on the heat pipe using water and $\mathrm{Al}_{2} \mathrm{O}_{3}-$ water at heating power (Q) of 10 Watt, 15 Watt and 20 Watt. The temperature along the heat pipe declines from the position of the evaporator to the condenser area. As can be seen in the figures, the temperature of evaporator using $\mathrm{Al}_{2} \mathrm{O}_{3}$-water has lower temperature than the heat pipe using water as a conventional working fluid. The evaporator temperature is getting lower with the increasing concentration of the nanofluid.

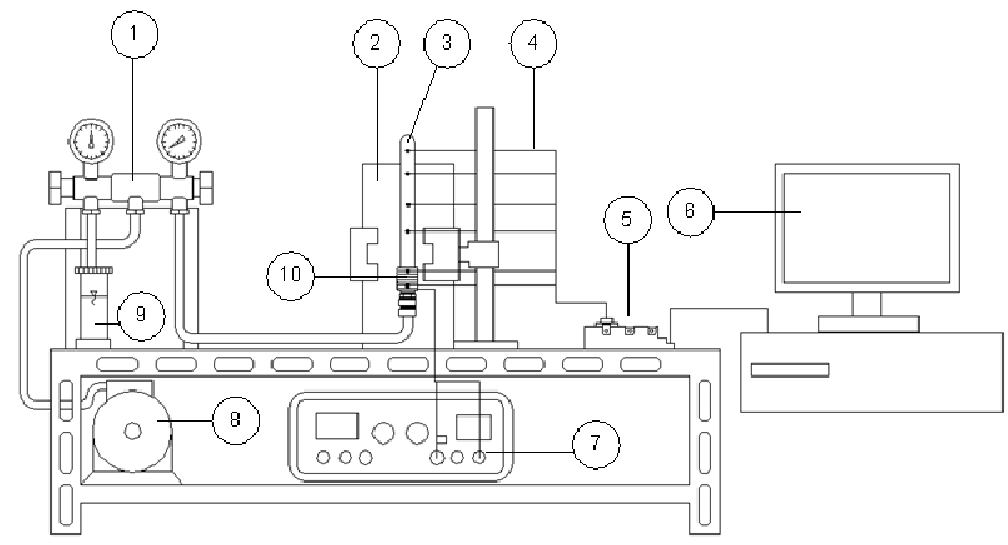

Fig. 5. Experimental Schematic.

\section{Annotation:}

1. Gage manifold

2. Polyurethane isolator

3. Heat pipe

4. Thermocouple

5. Chassis DAQ-9172+ NI 9211

6. PC unit

7. DC-power supply

8. Vacuum pump

9. Working fluid filling-tube

10. Cable heater

10.Cable heater

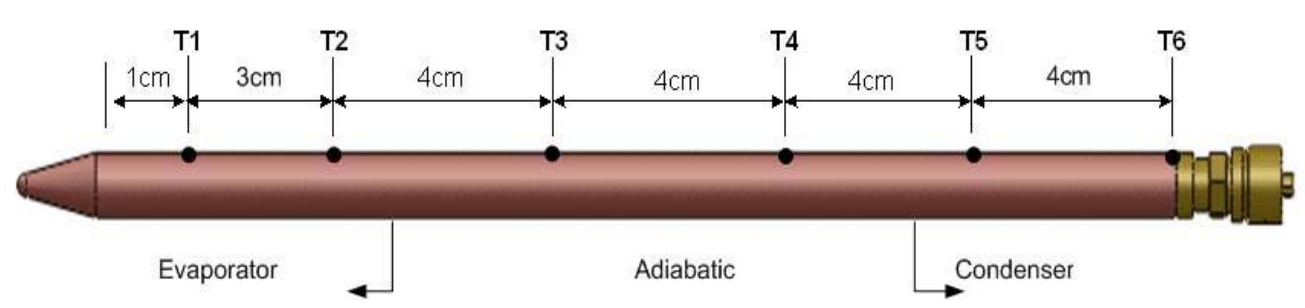

Fig. 6. Thermocouple position (T1-T6).

First, the thermocouples were placed at several point of the heat pipe. Then, the evaporator area of the
Thus, the evaporator temperatur is lowest for the $\mathrm{Al}_{2} \mathrm{O}_{3}$-water nanofluid with 5\% concentration. With 
the heat load (Q) of 10 Watt, the temperature decrease at an average of $25^{\circ} \mathrm{C}$ for $5 \%$ concentration, $23.5^{\circ} \mathrm{C}$ for $4 \%$ concentration, $14^{\circ} \mathrm{C}$ for the $2 \%$ concentration, and $9^{\circ} \mathrm{C}$ for the $1 \%$ concentration at the lowest. With the increasing of heat load $(\mathrm{Q})$ given at the evaporator area, the ability of nanofluid in reducing the temperature was also increasing. At the load of 15 Watt and 20 Watt, heat pipe with $5 \% \quad \mathrm{Al}_{2} \mathrm{O}_{3}$-water can reduce temperature by $30^{\circ} \mathrm{C}$ and $31^{\circ} \mathrm{C}$ respectively, compared to the usage of water. This indicates that higher concentration of $\mathrm{Al}_{2} \mathrm{O}_{3}$ in nanofluids have a good effect in reducing the temperature of evaporator. This result shows good agreement with the experiment conducted by Kang et al. [11] and Wei et al. [22] that the concentration of the nanofluid affect the performance of heat pipes.

The difference on temperature gradient at evaporator and condenser between various working fluid applications can be explained by the different thermal performance on each working fluid. Water with lower thermal conductivity, and lower convective heat transfer coefficient, absorbed smaller amount of heat from the heat source. The heat which was not absorbed raised the temperature of evaporator. Meanwhile at the condenser, only a small amount of heat was transferred to the ambience, and the transfer proceeded slowly so the temperature at the condenser is low. With a nanofluid, which has higher thermal conductivity and higher convective heat transfer coefficient than water, the heat transfer process proceeded rapidly. Heat from the heat source was rapidly absorbed and transferred to the condenser side. This rapid heat transfer resulted in lower temperature at evaporator and higher temperature at the condenser compared with those at the heat pipe with water, thus lowering the temperature gradient.

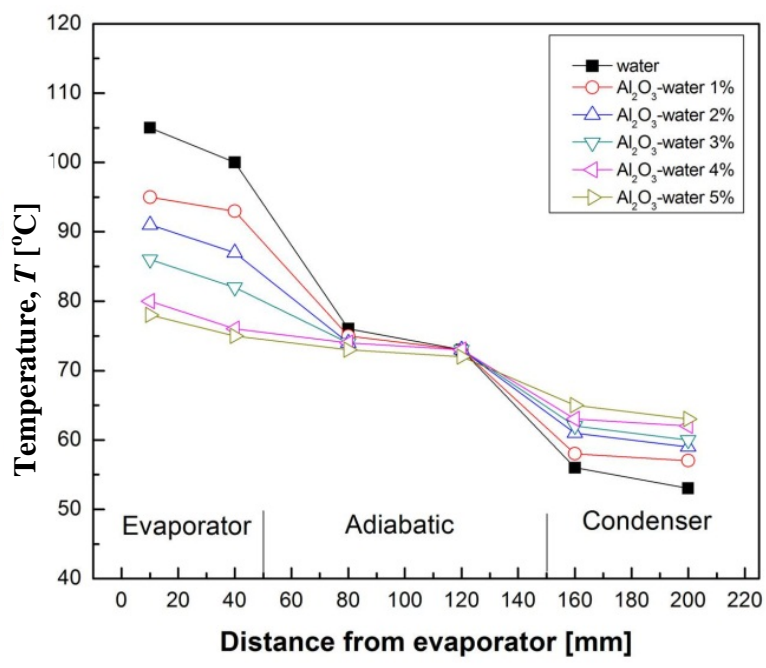

Fig. 7. Temperature distribution of heat pipe with water and $\mathrm{Al}_{2} \mathrm{O}_{3}$ as a working fluid at $\mathrm{Q}=10 \mathrm{~W}$.

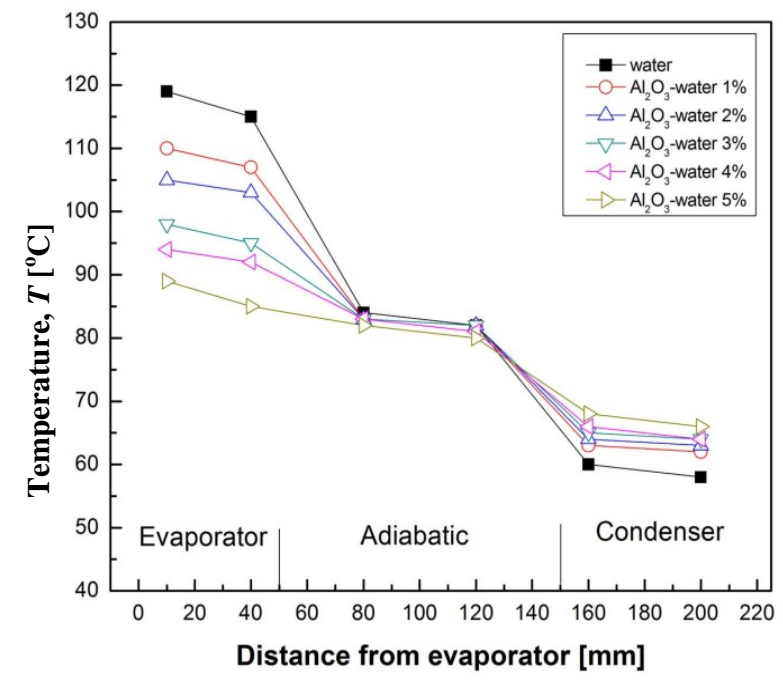

Fig. 8. Temperature distribution of heat pipe with water and $\mathrm{Al}_{2} \mathrm{O}_{3}$ as a working fluid at $\mathrm{Q}=15 \mathrm{~W}$.

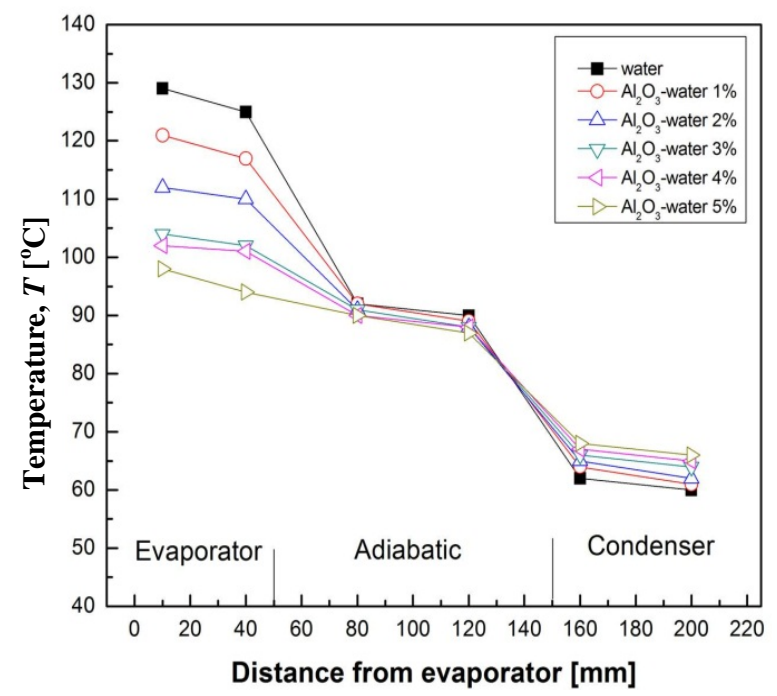

Fig. 9. Temperature distribution of heat pipe with water and $\mathrm{Al}_{2} \mathrm{O}_{3}$ as a working fluid at $\mathrm{Q}=20 \mathrm{~W}$.

The type of nanoparticles used in the production of nanofluid as the heat pipe working fluid also affects the performance of the heat pipe. Figs. 10, 11 and 12 show the temperature distribution along the heat pipe using water, $\mathrm{Al}_{2} \mathrm{O}_{3}$-water $1 \%$ and $5 \%$ and $\mathrm{TiO}_{2}$-water $1 \%$ and $5 \%$ as the working fluid. From the pictures it can be observed that the $\mathrm{Al}_{2} \mathrm{O}_{3}$-water has the ability to reduce the temperature in the evaporator better than the $\mathrm{TiO}_{2}$-water and water. $\mathrm{TiO}_{2}$-water capability in reducing the temperature at the evaporator is lower at average of $8 \%$ compared to the $\mathrm{Al}_{2} \mathrm{O}_{3}$-water. This happens because the value of the thermal conductivity of $\mathrm{Al}_{2} \mathrm{O}_{3}$-water is higher than that of $\mathrm{TiO}_{2}$-water; therefore, at the concentration of $5 \%$ $\mathrm{Al}_{2} \mathrm{O}_{3}$-water has thermal conductivity of $1.25 \mathrm{~W} / \mathrm{mK}$ and $\mathrm{TiO}_{2}$-water has thermal conductivity of 1.12 $\mathrm{W} / \mathrm{mK}$. The thermal conductivity measurement itself was conducted by using a KD2 thermal analyzer. 


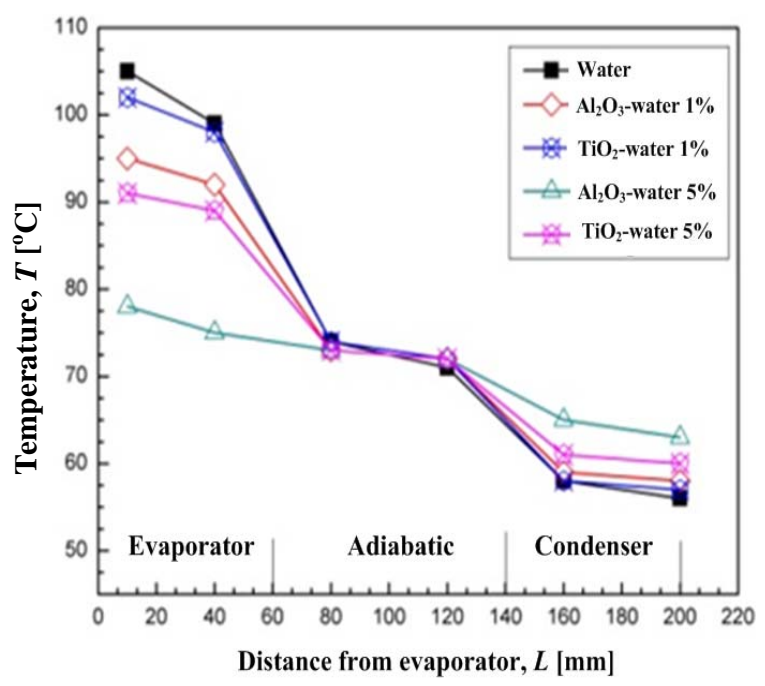

Fig. 10. Temperature distribution of heat pipe with $\mathrm{Al}_{2} \mathrm{O}_{3}$ and $\mathrm{TiO}_{2}$ as a working fluid at $\mathrm{Q}=10 \mathrm{~W}$.

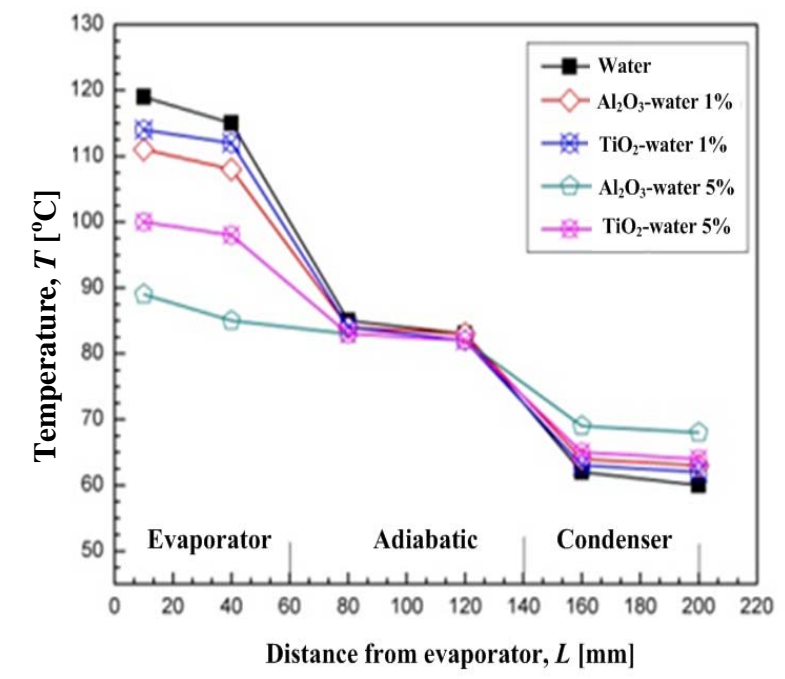

Fig. 11. Temperature distribution of heat pipe with $\mathrm{Al}_{2} \mathrm{O}_{3}$ and $\mathrm{TiO}_{2}$ as a working fluid at $\mathrm{Q}=15 \mathrm{~W}$.

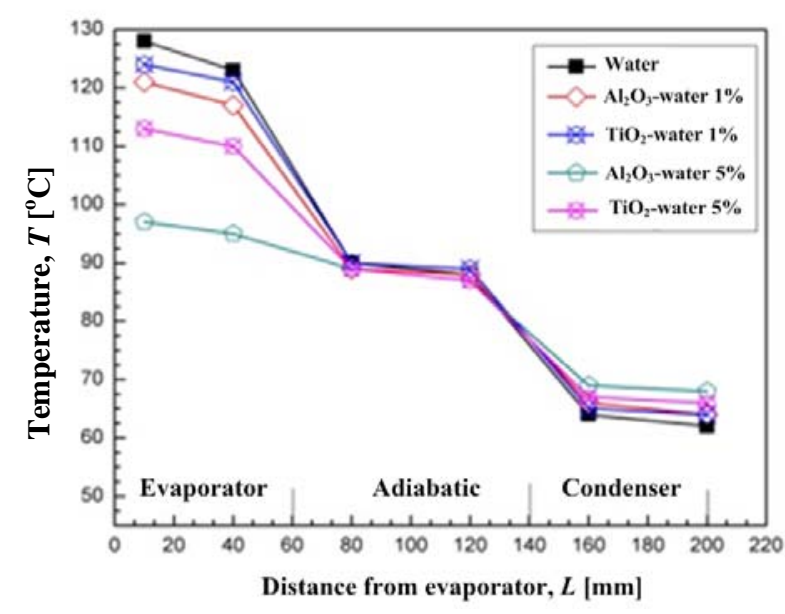

Fig. 12. Temperature distribution of heat pipe with $\mathrm{Al}_{2} \mathrm{O}_{3}$ and $\mathrm{TiO}_{2}$ as a working fluid at $\mathrm{Q}=20 \mathrm{~W}$.

The addition of nanoparticles into the base fluid resulting in the nanofluid exhibiting Brownian motion in which the nanoparticles are constantly moving. A very small particle size will increase the contact area between the surface of the particles so that collisions between particles occur more frequently. This resulted in a faster heat transfer process compared to that achieved with the conventional working fluid.

The thermal resistance of heat pipe in this study is referred to the work done by Do [23] where the thermal resistance of a heat pipe is defined as

$$
R_{e-a}=\frac{T_{e}-T_{a}}{Q_{i n}}
$$

where $T_{e}, T_{a}$ and $Q_{i n}$ are the average temperature of evaporator area, average temperature of adiabatic area, and the heat load respectively.

Fig. 13 shows the graph of the thermal resistance of the heat pipe when using water and nanofluids with $1 \%$ and $5 \%$ of $\mathrm{Al}_{2} \mathrm{O}_{3}$ and $\mathrm{TiO}_{2}$ as working fluid. In the graph, the largest thermal resistance occured in the use of water. Thermal resistances created by using nanofluid, both with $\mathrm{Al}_{2} \mathrm{O}_{3}$ and $\mathrm{TiO}_{2}$, tend to be lower than those occuring from the use of water as working fluid. At a heat load of 10 Watt, the thermal resistance value of heat pipe using water is $4.6^{\circ} \mathrm{C} / \mathrm{W}$ while for $1 \%$ and $5 \% \mathrm{Al}_{2} \mathrm{O}_{3}$-water the values are $4.3^{\circ} \mathrm{C} / \mathrm{W}$ and $1.1^{\circ} \mathrm{C} / \mathrm{W}$ respectively. The $1 \%$ and $5 \% \quad \mathrm{TiO}_{2}$-water have thermal resistance values of $3.6^{\circ} \mathrm{C} / \mathrm{W}$ and $2.8^{\circ} \mathrm{C} / \mathrm{W}$ respectively. The smallest thermal resistances were found in the use of $5 \% \mathrm{Al}_{2} \mathrm{O}_{3}$-water as the working fluid.

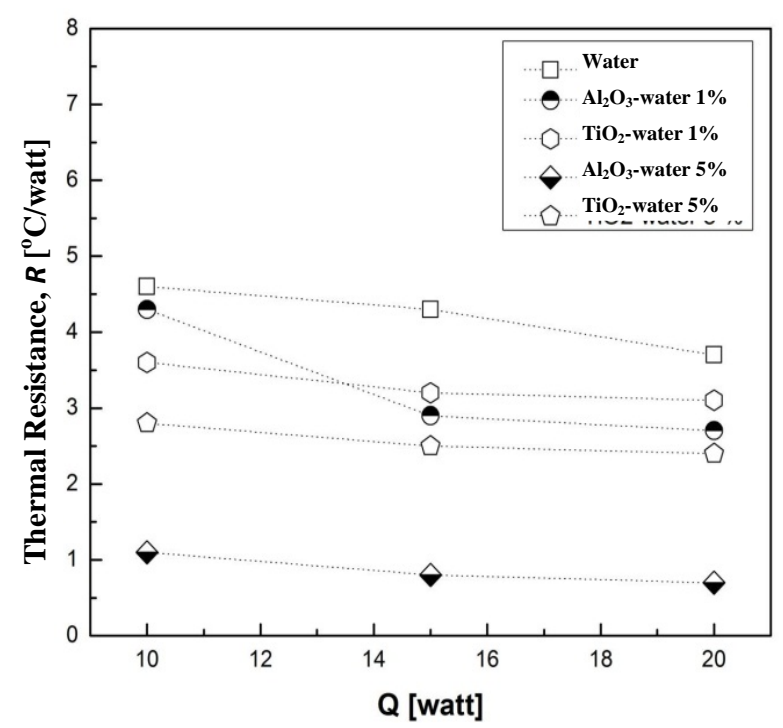

Fig. 13. Heat pipe thermal resistance at working fluid and heating load $(\mathrm{Q})$ variation. 
As Fig. 13 also shows, the thermal resistance of the heat pipe also tends to decrease with increasing heat load. Using water as working fluid, increasing the heat load from $10 \mathrm{~W}$ to $15 \mathrm{~W}$ and then $20 \mathrm{~W}$ resulted in the decrease of thermal resistance from $4.6^{\circ} \mathrm{C} / \mathrm{W}$ to $4.3^{\circ} \mathrm{C} / \mathrm{W}$ and then to $3.7^{\circ} \mathrm{C} / \mathrm{W}$, respectively. With other working fluids, the same trend was observed. For the same heat load levels, the thermal resistance values obtained were $3.6^{\circ} \mathrm{C} / \mathrm{W}, 3.2^{\circ} \mathrm{C} / \mathrm{W}$, and $3.1^{\circ} \mathrm{C} / \mathrm{W}$ for $1 \%$ $\mathrm{TiO}_{2}$-water; $2.8^{\circ} \mathrm{C} / \mathrm{W}, 2.5^{\circ} \mathrm{C} / \mathrm{W}$, and $2.4^{\circ} \mathrm{C} / \mathrm{W}$ for $5 \%$ $\mathrm{TiO}_{2}$-water; $4.3^{\circ} \mathrm{C} / \mathrm{W}, 2.9^{\circ} \mathrm{C} / \mathrm{W}$, and $2.7^{\circ} \mathrm{C} / \mathrm{W}$ for $1 \%$ $\mathrm{Al}_{2} \mathrm{O}_{3}$-water; and $1.1{ }^{\circ} \mathrm{C} / \mathrm{W}, 0.8^{\circ} \mathrm{C} / \mathrm{W}$, and $0.7^{\circ} \mathrm{C} / \mathrm{W}$ for $5 \% \mathrm{Al}_{2} \mathrm{O}_{3}$-water, respectively. In each load, the smallest thermal resistance occurs in the use of $\mathrm{Al}_{2} \mathrm{O}_{3}$-water at the concentration of $5 \%$. This happens due to the fluid's higher thermal conductivity compared to the other working fluid. $\mathrm{TiO}_{2}$-water has a higher thermal conductivity than water but still lower compared with $\mathrm{Al}_{2} \mathrm{O}_{3}$-water. Another factor that affects the excellence of $\mathrm{Al}_{2} \mathrm{O}_{3}$ is that at the same size, $\mathrm{Al}_{2} \mathrm{O}_{3}$ particles have a lighter mass than $\mathrm{TiO}_{2}$, making the Brownian motions on $\mathrm{Al}_{2} \mathrm{O}_{3}$-water greater than on $\mathrm{TiO}_{2}$-water.

The effects of nanoparticles to the screen mesh wick structure should be analyzed, since there are possibilities that the nanoparticle will change the physical structure of the wick. The change in physical structure would affect the ability of the wick to perform its function of transferring the working fluid from the condenser to the evaporator area. Thus, the physical characteristics of the wick should be analyzed both visually and substantially using SEM and EDS.

Fig. 14 shows the SEM picture of a screen mesh which has not been used as the wick in a heat pipe. The screen mesh is made of stainless steel 200 mesh with wire diameter of $\pm 56.5 \mu \mathrm{m}$ and with 67.416 weft wires per $\mathrm{mm}$. The screen mesh is captured by SEM with magnification of $200 \times$ and $500 \times$. The result from energy dispersive X-Ray Analysis (EDAX), as shown in Fig. 15, shows that the stainless steel mesh screen contains the elements $0.89 \%$ C, $1.74 \%$ O, $0.52 \%$ Si, $1.09 \%$ S, $15.56 \%$ Cr, Fe $66.07 \%$ and $14.13 \% \mathrm{Ni}$.

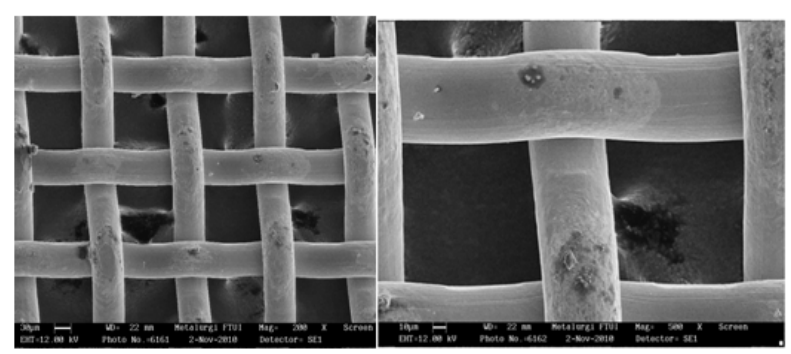

Fig. 14. Screen mesh before use.

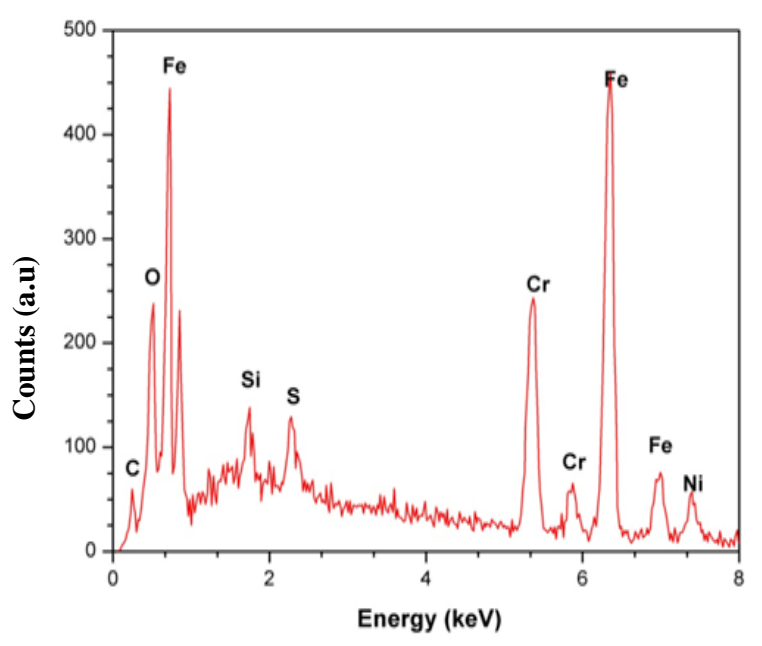

Fig. 15. The result of EDAX analysis of the screen mesh before use.

Figs. 16 and 17 show the condition of screen mesh after being used as wick in the heat pipe using $\mathrm{Al}_{2} \mathrm{O}_{3}$-water nanofluid. It appears that there are agglomeration buildups in the corners of the screen mesh weavings. EDAX analysis showed the addition of $\mathrm{Al}$ of $18.39 \%$ and $\mathrm{O}$ of $43.18 \%$ deriving from $\mathrm{Al}_{2} \mathrm{O}_{3}$ deposition. The content of $\mathrm{Fe}$, which is the main constituent of stainless steel with the initial content of $66.07 \%$, decline to $1.43 \%$. This result means that there is a thin coating on the surface of the screen material due to deposition from the nano$\mathrm{Al}_{2} \mathrm{O}_{3}-\mathrm{H}_{2} \mathrm{O}$ fluid. EDAX analysis also found a small portion of Ti. It is suspected that during the process of nanofluid production, there are still remnants of $\mathrm{TiO}_{2}$ particles at the probe of ultrasonic processor from the previous $\mathrm{TiO}_{2}$ nanofluid production. Then, during the production of $\mathrm{Al}_{2} \mathrm{O}_{3}$-water nanofluid, the $\mathrm{TiO}_{2}$ particles remains were co-dispersed to the nanofluid being made.

With $\mathrm{TiO}_{2}$-water working fluid, precipitation of nanoparticles from the nanofluid also coats the surface of the screen mesh, but unlike the case with $\mathrm{Al}_{2} \mathrm{O}_{3}$-water nanofluid, the sediment only lightly coats the screen surface without forming large agglomerations in the corner sections of screen woven as shown in Fig. 18.
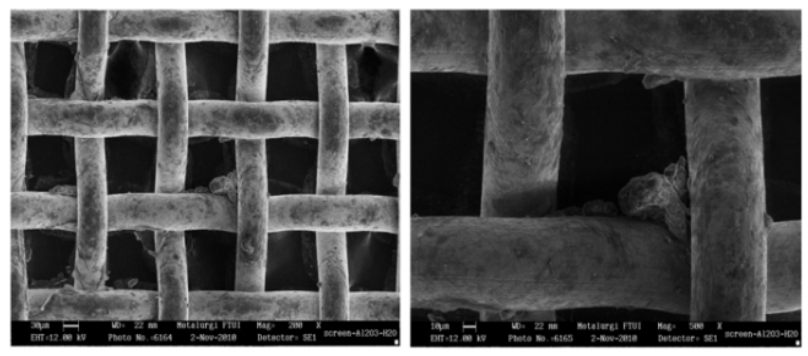

Fig. 16. Wick screen mesh after operation with $\mathrm{Al}_{2} \mathrm{O}_{3}$-water working fluid. 


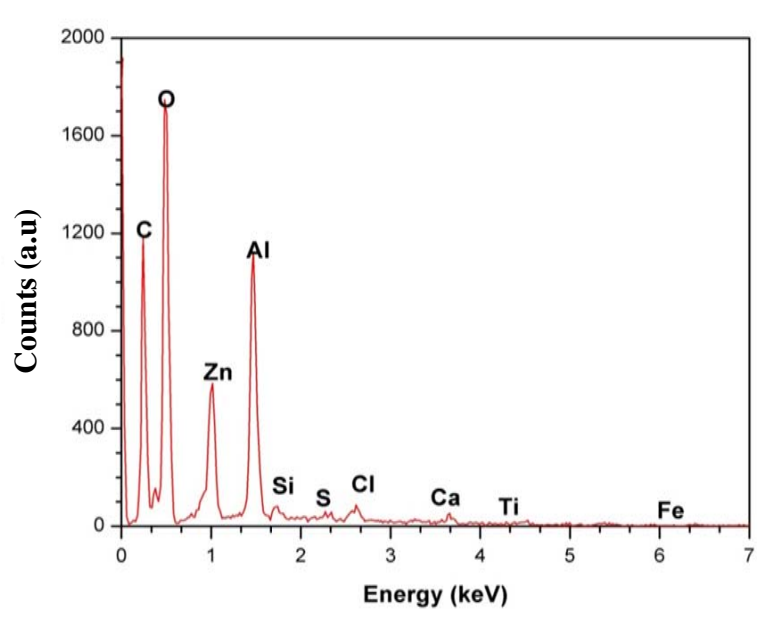

Fig. 17. The result of EDAX analysis wick screen mesh after operation with $\mathrm{Al}_{2} \mathrm{O}_{3}$-water working fluid.
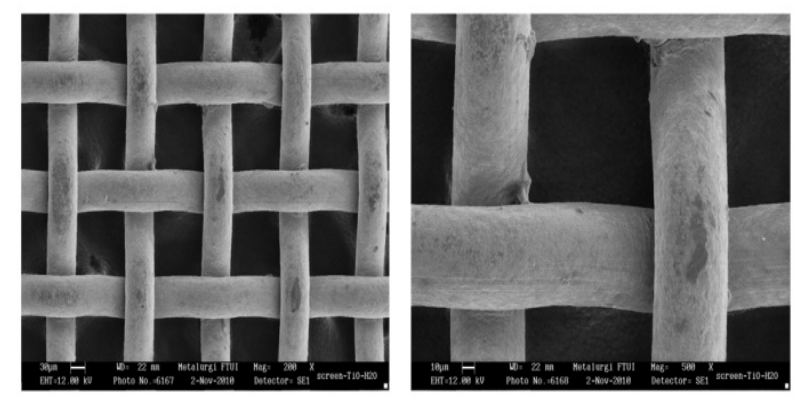

Fig. 18. Wick screen mesh after operation with $\mathrm{TiO}_{2}$-water working fluid.

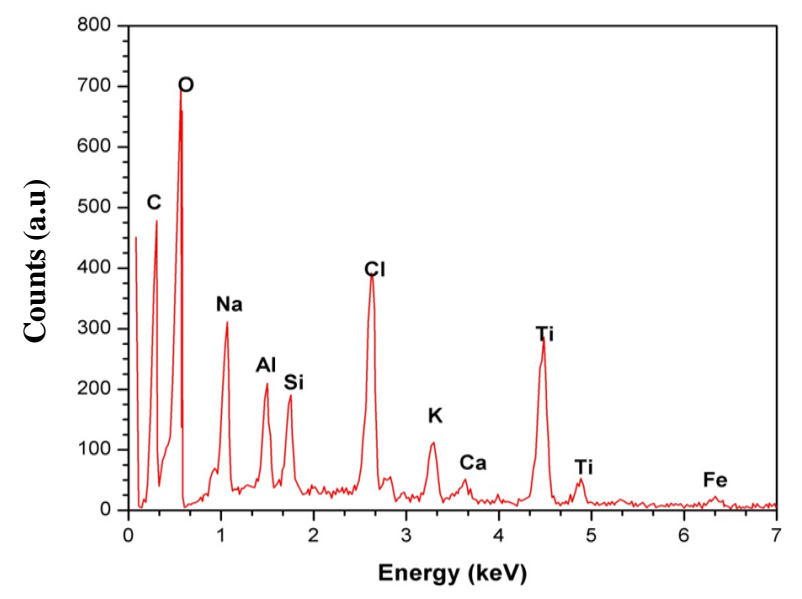

Fig. 19. The result of EDAX analysis of screen mesh after operation with $\mathrm{TiO}_{2}$-water working fluid.

Fig. 19 above is the analysis of screen mesh wick after the discharge of the $\mathrm{TiO}_{2}$-water, where the screen mesh is coated with $\mathrm{TiO}_{2}$-water deposition. This can be seen from the results of EDAX analysis that the surface of the screen is covered by $\mathrm{Ti}$ and $\mathrm{O}$ at $22.21 \%$ to $26.40 \%$. The coating by the deposition of $\mathrm{TiO}_{2}$ is large enough, seen by the Fe element that is left $2.85 \%$. It is still thinner than the coating by deposition caused by the use of $\mathrm{Al}_{2} \mathrm{O}_{3}$-water nanofluid. But in this case the structure of the screen did not change significantly; the geometry of the mesh on the screen still remain homogeneous.

\section{CONCLUSION}

From the discussion above, it can be concluded that the use of nanofluid as working fluid $\left(\mathrm{Al}_{2} \mathrm{O}_{3}\right.$-water and $\mathrm{TiO}_{2}$-water $)$ on the straight heat pipe with natural cooling can improve the performance of heat pipes in which the use of $\mathrm{Al}_{2} \mathrm{O}_{3}$-water nanofluid $5 \%$ can reduce the temperature by as much as $23.7 \%$, while the use of $5 \% \mathrm{TiO}_{2}$-water can reduce the temperature by $20.2 \%$ compared to what is attained by the use of water as the base fluid. The use of nanofluid as working fluid can also lower the value of the heat pipe thermal resistance.

The use of nanofluid as the working fluid causes thin sedimentation on screen mesh wick. Although this is not significant, the coating reduce the pore size of the mesh which could affect the capillary performance.

\section{ACKNOWLEDGMENT}

We would like to express our thanks to DRPM UI, which has funded this research through the Grants Graduate programs 2010, and to the Applied Heat Transfer Research Group which has been providing tools which support the implementation of this study.

\section{REFERENCES}

1. Anonymous, Indonesian Presidential Regulation No.5 of 2006 about National Energy Policy, Jakarta (2006). (In Indonesian).

2. Anonymous, Safety Related Terms for Advanced Nuclear Plants, IAEA-TECDOC626, IAEA, Vienna (1991) 7.

3. N. S. Syam et al., Application of Passive Safety System on Nuclear, Proceeding of Scientific Meeting, XXV HFI Jateng \& DIY, Yogyakarta (2011) 43.

4. N. Putra, Wilfried, Roetzel and S. K. Das, International Journal of Heat and Mass Transfer 39 (2003) 775.

5. H. Jouhara, V. Anastasov and I. Khamis, Desalination 249 (2000) 1055.

6. I. I. Sviridenko, Applied Thermal Engineering 28 (2008) 327. 
7. N. Putra, Wilfried, Roetzel and S. K. Das, International Journal of Heat and Mass Transfer 39 (2003) 775.

8. S. K Das, N. Putra and W. Roetzel, International Journal of Heat and Mass Transfer 46 (2003) 851.

9. S. K. Das, N. Putra and W. Roetzel, International Journal of Multiphase Flow 29 (2003) 237.

10. N. Putra, Potential Development of Nanofluid as Alternative Working Fluid, http://eprints.ui.ac.id/id/eprint/860. Retrieved in December (2003).

11. S.W. Kang, Effect of Nano-fluid Concentration on Heat Pipe Thermal Performance, Department of Mechanical an ElectroMechanical Engineering, Tamkang University, Taiwan (2008).

12. K. H. Do, H. J. Ha and S. P. Jang, International Journal of Heat and Mass Transfer 25 (2010) 5888.

13. P. Naphon, P. Assadamongkolc and T. Borirak, International Communication in Heat and Mass Transfer 35 (2008) 1316.
14. L. Z. Hua and Q. Q. Zhu, Energy Conversion and Management 52 (2010) 292.

15. S. P. Jang, Journal of Heat Transfer 129 (2007) 617.

16. J. Koo and C. Kleinstreuer, International Journal of Heat and Mass Transfer 48 (2005) 2652.

17. S. M. You and J. H. Kim, Appl. Phys. Lett. 83 (2003) 3374.

18. S. M. Kwark, R. Kumar, G. Moreno, J. Yoo and S. M. You, International Journal of Heat and Mass Transfer 53 (2010) 972.

19. J. M. Ochterbeck, Heat Pipe, Departement of Mechanical Engineering, Clemson University, South Carolina 1182.

20. J. A. Easmant, S. U. S Choi and S. Li, Appl. Phys. Lett. 78 (2001) 718.

21. L. L. Vasiliev, Applied Thermal Engineering 25 (2005) 1.

22. W. Wei, S. H. Tsai, S. Y . Yang, et al., Applied Thermal Engineering 26 (2006) 2377.

23. K. H. Do, H. J. Ha and S. P. Jang, International Journal of Heat and Mass Transfer 25 (2010) 5888. 